social scientists (see, for example, D. Edgerton Nature 455, 1030$1031 ; 2008)$. But many funders and science policy-makers see the relationship in more straightforward terms: more science eventually provides valuable social returns, including greater wealth, education and a skilled workforce.

Even the oil-producing states of the Middle East - which have enjoyed good living standards without spending on science and technology - are coming round to this view. The largest-ever universitybuilding programme in the region's history is now under way, financed for the most part by the extra income from high oil prices.

As the price of oil (and other commodities) drops along with confidence in the markets, the strategy of investing more in science is going to be tested to the hilt. The larger developing countries should be able to weather the storm - in part because the state is a relatively larger player in research, compared with more developed countries. If private-sector R\&D begins to decline, it should still be possible for the state to maintain investment at - or near - current levels.

Smaller (and poorer) countries will have a harder time. Many are already borrowing from institutions such as the International Monetary Fund (IMF), and their priority will be to increase spending on welfare programmes. But those that want to stay on the present path have more grounds for hope than was the case in past economic crises.

In the 1980s, for example, countries that borrowed from the IMF and from the World Bank were told to cut back on government spending. Science and higher education were two of the biggest casualties, and in a few countries the effects can still be seen. In 2008, the mood couldn't be more different. In their response to the financial crisis, many developed world governments are talking not of cutting back, but of rebuilding and strengthening public institutions. In addition, there is a consensus that the world's financial architecture needs reforming too. Given such an environment, it will be difficult to justify asking poorer countries to cut back on their knowledge infrastructure when richer countries will be doing the opposite.

There is no doubt that the next few years will be difficult, but for the countries of the developing world, the answer to their present problems is not to undo the gains of the past quarter-century.

\section{A risk worth taking}

\section{An experiment by the Gates Foundation is food for thought for other research agencies.}

2 arry Marshall and Robin Warren's unorthodox idea that the bacterium Helicobacter pylori was involved in gastritis and peptic ulcers met with ingrained resistance from the guardians of stomach-acid wisdom in the 1980s. Against the odds, the two prevailed, revolutionizing care of the disease and receiving a Nobel prize in 2005. But how many other potentially groundbreaking ideas are dragged down a dark alley and quietly strangled by overly conservative peer review of grant proposals?

Research funding should strive for a balanced portfolio that includes both safe investments and higher-risk work. While the world's financial system has been inflated with wildly excessive risk, research funding has had the opposite problem - exacerbated by ever greater competition for limited funds, it is overly wedded to safe, unadventurous research. This, in effect, ostracizes off-the-wall ideas, which often cross disciplinary boundaries and would have potentially big payoffs should they work. Researchers long ago learned that the last people they should tell about their big ideas are their sources of financial support.

To be fair, there are exceptions to such conservatism. The US National Institutes of Health, for example, has systematically promoted risky research through several initiatives (see http://nihroadmap. nih.gov/highrisk), although the jury is out on its scientific impact. Military imperatives for innovation led the US Defense Advanced Research Projects Agency to transgress the conventions of academic business-as-usual, with undisputed success.

In a similar vein, frustrated with repeatedly encountering the same faces from the same countries, and a narrow range of ideas, the Bill \& Melinda Gates Foundation decided to cast the net wider in the search for new people and ideas. Last week, it announced the 104 winners of the first round of its five-year, US\$100-million 'Grand Challenges
Explorations' programme. This solicited unconventional ideas for protecting against infectious diseases, limiting drug resistance and exploring latent tuberculosis. Future rounds will include ideas for vaccines for killer diseases and tools to help eradicate malaria.

It is the nature of the call for proposals, and their peer review, that is intriguing. The grant proposal is one that many researchers can only dream of - a two-page explanation of the idea, with no supporting data required. To emphasize that it's the idea that matters, reviewers were blinded to the name, profession and nationality of the applicant.

The reviewers themselves were atypical. Instead of consensus review by experts in the field - as is the norm - the 4,000-odd proposals received were sent to individuals, not just in science but also in engineering, business and beyond - people the foundation considers to be 'champions' with strong track records in high-risk research.

It is too soon to assess the projects' chances of success, but what is clear is that many of the projects and their proponents are very different from those in conventional global-health research. They include work to explore links between natural HIV-resistance and genetic markers for type 2 diabetes, a proposal from an astrophysicist to reduce transmission of malaria with a flashlight that would disorientate mosquitoes, and testing the bacterium Bdellovibrio, which predates on many Gram-negative pathogens, as a living antibiotic.

The first-round grants, at $\$ 100,000$, are small. Dishing out large sums of money on far-fetched ideas would be foolhardy, given that as many as nine out of ten of these projects are expected to fail. But those that show signs of success will be eligible for further funds of $\$ 1$ million, or much more. All told, however, the entire programme amounts to just $10 \%$ of the Gates Foundation's new Global Health Discovery wing, which itself accounts for just $20 \%$ of the organization's overall global-health research budget.

Such levels of investment seem sensibly aligned with levels of risk. Risk-taking brings new faces and ideas to the table at reasonable cost and spurs creativity. Research agencies everywhere need to take a hard look at their funding portfolios to ensure that they are investing sufficiently in high-risk and potentially transformative research. 